\title{
Distributional issues in the operation of rights-based fisheries management systems
}

\author{
Guyader Olivier ${ }^{1,{ }^{*}}$, Thebaud Olivier ${ }^{1, \text { a }}$ \\ ${ }^{1}$ Service d'Economie Maritime IFREMER BP 70, 29280 Plouzane, France \\ * Corresponding author : Olivier Guyader, Tel.: +33-2-98-22-43-65 ; \\ email address : olivier.guyader@ifremer.fr
}

\begin{abstract}
:
Rights-based management regimes are considered by economists as an important solution to the problems of excess capacity and biological over-harvesting of fisheries. In practice, adoption of such regimes, and particularly of those relying on individual quota allocations, has often met with resistance from within the fisheries concerned. A key reason for this resistance appears to be the distributional conflicts which arise in the process of implementing the regimes. An economic analysis of the nature of these conflicts in the different contexts in which they have been observed is proposed. The approach centres on the way in which distributional conflicts can influence the operation of management systems and their impacts on fisheries, from the country to the individual firm level. As an illustration, an analysis of the economic processes at firm level is developed based on the simulation of a fishery managed under individual transferable quotas.
\end{abstract}

Keywords: Fisheries management, Rights-based management, Individual transferable quotas, Distributional issues, Economic simulation

${ }^{a}$ This article is based on work presented at the "Workshop on the definition and allocation of use rights in European fisheries. Brest, France 5-7 May 1999", EU concerted action on economics and the CFP. Coordinator: CEMARE, University of Portmouth, UK; and at the second conference Universite de Bretagne Occidentale/Université du Québec à Rimouski, Brest, 27-28 October 1999. The analysis presented in this article is that of the authors, and does not necessarily reflect the views of Ifremer. 
"If economics is to advise policy, it seems difficult to believe that the distributional issue can simply be swept aside. The issue of who is to receive the wealth associated with the fishery and the impact that this wealth will have on the regional and national economy is intimately linked to the kind of management system adopted and the way in which it is implemented. In formulating advice on the implementation of management systems, therefore, economics should consider the distributional as well as the efficiency implications of policy options" ([31]: 251).

Conventional economic approaches to fisheries management build on the well-known model of free and open access renewable resources. This model is centred on the identification of a level of efficient operation, defined as that which provides the maximum net returns to inputs in comparison with other economic sectors. Analysts seek to determine the levels of harvest at which economic efficiency will be achieved, and to identify policy measures needed to achieve such levels in the face of market failures. These failures originate from the lack of definition of rights to the resources, the resulting absence or imperfection of markets for them, and the externalities that this entails.

A particular class of phenomena which these studies have allowed to explain is the race for a share of the catch, in fisheries where only total capture is being restricted. It is now well understood that such management measures result in inefficient outcomes, where "too many vessels chase too few fish". To restore efficiency in these open access managed fisheries, economists have suggested that fishing rights to resource flows be explicitly allocated to individual harvesters [1]. By ensuring a fixed share of the catch to harvesters, such an allocation avoids the derby effect due to open access : it can generate efficiency gains given that harvest activities can be planned temporally to take advantage of market demand and, in some cases, of other fisheries, and given that operating costs can be reduced in the absence of "race for fish" conditions. A further step towards economic rationalisation of the fishery is to allow the subsequent allocations of fishing rights to be determined by bargaining between economic agents on an open market $[2,3,4,5,6,7]$. The implication is that, if agents can freely trade 
rights under conditions of perfect competition, these will end up in the hands of those who value them most, i.e. those who are most efficient in using them, whatever the initial allocation ${ }^{2}$.

While economists have been advocating the adoption of such management regimes for some time, the cases in which explicit allocation of rights to fish flows have been established as a basis for the regulation of capture fisheries remain limited in number. In practice, plans to restrict entry and allocate rights to catch to a limited number of participants have often met with strong opposition.

Scott [3] underlines the fact that, under various international treaties dating back to the beginning of the century, commissions were created with powers to co-ordinate national fishery controls. While these commissions often implemented national quotas, member states generally did not distribute these as individual quotas, and instead licensed vessels to participate in the international fishery [3]. More recently, evaluations of the consequences of extended fisheries jurisdiction have emphasised that increased national control over fisheries did not lead to the expected improvements in terms of limited entry $[8,9,10,7]$. Furthermore, where catch allocations have been established, an extensive length of time was needed before the opposition to the allocation schemes could be overcome [11].

The main reasons for these difficulties appear to be related to wealth distribution issues : as Macinko [12] underlines, any form of access control - or alteration of an existing access control regime - entails a specific distribution of benefits advantaging some participants over others. The resulting conflicts have been recognised by some authors as a major obstacle in the way of efficient management of ocean fisheries $[13,14,15,16]$. The nature of these conflicts has been interpreted following two general lines of analysis.

\footnotetext{
${ }^{2}$ This conclusion rests on a number of analytical and practical assumptions. From an analytical perspective, the idea of a market for fishing rights identical in principle to the market for a private good is usually seen by economists as the main alternative to "command and control" regulation of fisheries, or to intervention by a public agency based on less tractable taxing schemes. For the market to be efficient requires that a number of conditions be met, including the divisibility and transferability of rights, and the presence of a sufficient number of separate owners to ensure competitive behaviour. Moreover, for the initial allocation to remain neutral, there must be no costs linked to the establishment, enforcement and exchange of rights, and no income effects related to trade in rights. From a practical perspective, it has been shown that the implementation of such rights-based regimes may involve certain difficulties (e.g. monitoring and enforcement problems), and spillover effects (e.g. bycatch and discards, or redirections of fishing effort to other fisheries), which may undermine the overall benefits expected from these regimes (see $[17,18]$ for a discussion).
} 
The first line of analysis is in terms of equity and accepted rules of fairness. For example, fishery participants have been shown to prefer input regulations to the allocation of access rights in terms of output [15]. One reason advanced to explain this is that participants consider that it gives equal opportunity to every participant to use his skills and rewards the most skilful, which they see as fair $[19,20]$.

The second line of analysis is in terms of rent seeking behaviour [21]. For example, authors have shown that the ability to make decisions on wealth distribution can be inversely related to the degree of vested interests in the fishery. Thus, according to [16] it is not surprising that countries with the most advanced catch allocation regimes are those where the fisheries are the youngest (New Zealand and Australia), while in areas where the history of fisheries is longest, and employment is well established (Northeast Atlantic), problems are much greater.

Whatever the interpretation, it is thus widely accepted that distributional issues have a strong potential to affect management systems, and in particular those which set out to resolve the overcapitalisation problem. This paper investigates how economic analysis can help in understanding the implications of this for the operation of fisheries management systems. It is constructed in two parts. Part One reviews the existing literature on distributional issues in fisheries management, and develops a framework for the interpretation of these issues from an economic perspective. It then examines some of the empirical evidence in support of this framework at the international, national and fleet and firm levels. Part Two builds on the empirical evidence at fleet and firm level, and develops a simple model of quota trading, in order to simulate the effects of various distributional scenarios on the management system.

\section{I - Distributional issues in fisheries management : an economic perspective.}

A review of the literature shows that economists have generally been aware of the importance of social and political objectives - such as the safeguarding of life-styles, the maintenance of employment in regions where labour mobility is low (and economic opportunities are scarce), or the stabilisation of coastal communities - in fisheries management. However, as [22] notes, they have been reluctant to 
include these objectives in their analytical approach to fisheries management. Rather, such objectives have been included as components of a more general discussion of fisheries policy issues (e.g. [23, 24, $21,25])$, or taken into account in empirical studies of the distributional implications of particular management systems [see [26] for a recent review and [27] for particular case studies]. Few papers seem to have been specifically devoted to the development of an analytical perspective on distributional issues in fisheries management ${ }^{3}$.

More than twenty years ago, [28] suggested an analytical framework that sought to include distributional effects in the economic assessment of fisheries policy options. The authors stressed the fact that treating efficiency aspects only would lead to incomplete assessments. Using standard welfare economics, they argued that, for both theoretical and practical reasons, a concept of distributionallypreferred outcomes should also be taken into account, leading to the definition of a set of acceptable distributions for the selection of policy options.

If one adopts this framework, the difficulty - which also seems to be the reason for the reluctance of economists to include distributional issues in their applied analysis - becomes how to assess the social acceptability of policy options from a distributional perspective. Copes [29] expresses the nature of this difficulty in the following terms :

"In attempting to improve welfare we are faced simultaneously with trying to increase the size of 'the pie' and distributing it in a socially more equitable (valuable) way. The task is rendered difficult and ambiguous because of changes in size and composition of the value-measured pie consequent to interdependent changes in wealth and income distribution, production and market values. Pursuit of greater size of the pie (i.e. greater value of output) and socially more valuable distribution are interdependent, but not fully compatible, so that any notion of maximizing social welfare requires a designation to be made of an optimal trade-off" (64).

As Armstrong and Clark [26] state, the question of what is to be accepted as a socially preferred allocation of resources has developed into many diverging theories, and has led some authors at least to conclude that no universal criteria exist for the assessment of policy alternatives from this perspective : in practice, different situations may call for different distributional criteria ${ }^{4}$.

\footnotetext{
${ }^{3}$ For examples of existing analytical approaches, see [30, 28, 31, 26, 29].

${ }^{4}$ In the context of fisheries, based on the Norwegian case, Armstrong and Clark [26] argue that there is a tendency to place greater emphasis on distributional issues when the harvested stocks are low, while there appears to be a shift towards efficiency criteria when the stocks become large enough.
} 
Such difficulties were acknowledged by Bromley and Bishop [28]; the authors however suggested that, even if economics could not yield clear advice about distributionally preferable options, distributional implications of alternative courses of action should be made as explicit as possible in economic assessments. Given the practical importance of distributional issues, there is little doubt that such assessments would have the potential to be considered by fisheries managers as an essential contribution of economic studies.

In this paper, a slightly different route is adopted. Rather than focusing on distributional implications of policy measures, and the problem of their social acceptability, we start from the assumption that wealth distribution affects the ways in which management systems operate. The aim then becomes to represent the mechanisms at stake, and to develop an analytical framework which can be confronted to empirical research in order to gain a better understanding of how management systems behave. The starting point for this approach is to analyse the way in which we may need to modify representations of the behaviour of decision units targeted by management. We then turn to empirical evidence in support of this analysis, before developing a simple model to simulate the consequences of distributional issues on the operation of management systems.

\section{Distribution and the behaviour of economic decision units.}

As in other areas where economic analysis has been applied to environmental regulation, the study of fisheries policy has developed on the assumption that efficiency is the guiding principle for selecting policy instruments, and has relied on the standard neo-classical model of rational behaviour to explain the acts of decision units targeted by management systems. The usual assumption is that these agents act as autonomous individuals, following a behavioural principle of profit / utility maximisation under technical / budget constraints.

An important issue which has attracted fairly little attention is the fact that the decision units considered in these approaches most often are not individual people, but groups of various kinds - e.g. households, fishing firms, producer organisations, recreation clubs, governmental organisations, states - which behave according to more or less structured principles of a collective nature. Recent work in 
marine fisheries [32, 33], and in other environmental policy contexts [34] shows that for such economic agents, the implications of the rational behaviour assumption may vary, as the processes of organisation internal to these collective decision units may have a strong influence on their "external", observable, behaviour. In particular, it may be that different "sub-groups" within the same collective pursue differing objectives, and predicting group behaviour will then require an understanding of the internal processes by which sub-group actions are co-ordinated.

It then becomes difficult to speak of the consequences of a particular management scheme on "the fishing industry" or "the fishermen" without paying specific attention to the way in which these collective agents behave internally in the face of management measures. This is in contrast with standard economic texts on fisheries management where analysis is usually cast in the following terms :

"Well working community based fisheries management schemes and well working ITQ schemes share a common attribute. They will both give the fishermen an incentive to view the fishery resources as long term assets, the conservation of which is in their self-interest" [7: 28, emphasis added].

Scott [3] stresses this point in his analysis of the opposition of members of the fishing industry to the implementation of ITQ systems. He acknowledges the fact that the term "industry" can be taken to describe individual fishermen, fishermen groups, or fishing companies, with different consequences in terms of behavioural assumptions in each case. Furthermore, in the conclusion of an article which partly centres on distributional obstacles to the development of limited access in fisheries, Scott [15] recommends that economists turn to the ways in which to model and predict the problems and failures of fisheries groups, communities and co-operatives, rather than getting trapped in the economics of individualistic regulated fisheries.

In the context of rights-based management systems, an issue of particular importance is the way in which distributional conflicts internal to economic decision units can affect the collective preferences of these agents, and their behaviour in the allocation process itself. While it is usually assumed that the structure of individual preferences and production functions is given in economic models of use rights allocation, this may result in links between the way in which wealth distribution issues are resolved within decision units and the external strategies adopted by these units. If such links exist, the main 
implication from a policy perspective is that the consequences of management measures which have wealth distribution effects may be less predictable, as they depend on the way in which these effects will be spread within, and between, economic agents, and how this will affect their behaviour.

Several examples of this problem can be found in empirical case studies.

\section{Elements of empirical evidence.}

Standard fisheries economics reasoning has been applied at a variety of scales, from the international scene to the local fleet level. In each case, the definition of the relevant decision unit is changed to account for the scale at which decisions are being observed [33] : e.g. national fleets / states in the international arena, sectoral fleets / administrations in the national context, individual firms at the local fleet level. In most cases, the decision units are collectives. It thus appears possible to discuss the assumptions underlying representations of individual behaviour in the different contexts in which they have been applied.

\section{Distributional effects at the international level.}

At the international level, decision units usually considered in fisheries economics studies are individual countries. Where game theory has been applied, these are assimilated to rational players, with similar behavioural implications as in the standard neo-classical framework [7]. Here, the distributional problem takes a specific form, as there is no supra-national authority which can enforce a specific allocation of rights. The issue is one of self-organisation through bargaining and leads to analysis in terms of expected losses from competition / gains from co-operation.

Hannesson [35] provides an analysis of the Norwegian fisheries policy which illustrates the difficulties involved in making assumptions with regards to the behaviour of countries as economic agents on the international scene. According to the author, Norway's policy is a good example of the adoption by a country of economically inefficient options, because of a deliberate trade-off between efficiency and equity at the national level. He states that the country's fisheries policy has primarily been one of supporting fishermen's incomes and maintaining the level of employment, within a policy process 
resting on extensive consultation of fishermen's organisations by government. Copes [29] and Hannesson [10] also stress the prominence of employment and fishermen's income in explaining the policy choices made by various countries including Canada in Northeast Atlantic fisheries. In a similar vein, Boncoeur and Mesnil [36] stress that the position adopted by European governments in the negotiation of Common Fisheries Policy measures is strongly influenced by concern for the short term minimisation of conflicts between fishermen, and between authorities and fishermen interest groups.

\section{Distributional effects at the national level.}

At the national level, the distributional issue could theoretically be solved through the intervention of a central authority, acting as the sole owner of resources placed under its sovereignty and/or jurisdiction. In practice, as the above discussion shows, there will be several groups with differing interests in the fisheries, and the difficulties linked to the allocation problem will be replicated at this level. The development of rights-based management systems will encounter opposition from groups who feel their entitlement to the fishery (e.g. customary use, commercial harvesting, recreational fishing, general public interest) has not been taken into account, leading to the questioning of the acceptability and legitimacy of the management system. As Bromley [30] states, where there are several groups seeking permission to fish, the usual suggestion would be to sell or lease fishing rights, thus extracting some of the rent for the state, and insuring that those who value fishing the most would access the fishery. Practice shows that the process is one of conflicts between potentially overlapping groups which claim an entitlement to fisheries resources, and that this process depends on how each group is itself organised as a collective and represented at the national level. Part of the problem then becomes that groups may not be totally homogeneous in their objectives, leading to a behaviour in the intergroup negotiation process that cannot easily be boiled down to efficiency considerations.

Various examples can serve to illustrate this. In understanding the position of "the fishing industry", it may prove necessary to distinguish the processing sector from the catching sector. Matulich et al. [37] show that the advancement of ITQ policies in the United States, particularly the North Pacific fisheries being considered for ITQ management, is blocked by the fact that traditional ITQ systems allocate 
rights only to the latter, ignoring interests of the former. Sharp [38] and Memon et al. [39] address current policy issues in the quota management system set up in New Zealand. They describe how the system has been forced to evolve from an initial allocation to commercial fishermen only, to an allocation between commercial fishermen, Maori fishermen and recreational interests.

Other studies have focused on issues of regional development in the definition of national allocations of fishing rights. These studies show that important groups of interests to consider in the decision process are the local authorities whose aim is to maintain activity on their territory. Macinko [12] describes the important role played by such local authorities in the evolution of the management system for halibut and sable-fish fisheries in Alaska. Charles [24] stresses the interdependence between efficiency objectives and what he calls "socio-economic sustainability considerations", in which he includes employment stability, or equitable wealth distribution with particular attention to the development of rural areas. Cunningham [31] also stresses the importance of regional development stakes in the process of national fisheries management.

\section{Distributional effects at fleet/firm level.}

At this level, again, the issue of how wealth is allocated between component interests in the fishery is encountered. Decision units in this case are the firms affected by the management system. If firms themselves are considered as collectives, their behaviour can be affected by the way in which they are internally organised, and particularly by existing contracts and bargaining relationships between capital owners, quota owners and crews. Indeed, these have been shown to constitute a central factor in explaining the evolution fisheries under a number of ITQ regimes ${ }^{5}$. The key variables that will usually serve to assess the nature of these bargaining relationships are the levels of employment and the remuneration of crew work ${ }^{6}$.

\footnotetext{
${ }^{5}$ As Wilen et al. [46] state: "Although vessel owners have been primary recipients of quota in most cases, the character of many programs has been influenced to some degree by concerns of crew members about how ITQs might change circumstances for them. Labor unions representing crew members have been particularly active in negotiation over system design with the aim of reducing adverse impacts on crew labor" (p331).

${ }^{6}$ In certain cases, concern for such distributional implications within fleets has resulted in the imposition of constraints on quota trade, in order to limit quota-aggregation possibilities. On the political scene, the conflicts
} 
Recent reviews of ITQ systems around the world show that as a general rule, in individual quota schemes, catch shares have been given out to capital owners, allowing them to benefit from windfall gains $[40,29,41]^{7}$. The distributional conflicts generally observed in these cases relate to phenomena such as quota aggregation, reduction in employment of fishermen and increased competition on the labour market, increase in the intensity of work for active fishermen, and/or changes in the remuneration of fishing jobs. Below, we consider published evidence of employment and remuneration effects.

In terms of employment effects, cases such as the southern bluefin tuna fishery in Australia [42, 43], the halibut fishery in British Columbia [44], or the surf clam and ocean quahog (hereafter SCOQ) fisheries in the United States [45] do show short term sharp reductions in fleet sizes and levels of employment. In the latter fishery, which is subject to no restrictions on quota trading, vessel numbers have fallen from 128 to 53 between 1990 and 1994 while labour has declined by thirty percent over the same period [45]. In the Canadian halibut fishery, decrease in employment (in terms of numbers of fishermen) has reached $32 \%$, composed of an estimated $18 \%$ reduction in crew size on active vessels and a $14 \%$ decrease due to crews being displaced from non active vessels $[44]^{8}$.

Another phenomenon which the Canadian halibut case serves to illustrate is the fact that, if individual quotas are established in a fishery in which "labour stuffing" occurs, this will give rise to higher rates of labour utilisation, where active crews work much more days and longer hours, causing complaints and decreasing work safety at sea in some cases. Such phenomena are stressed in several case studies : e.g. the Nova Scotia mobile gear fishery [48], the offshore groundfish enterprises in Canada [49], the SCOQ fishery [11], or the Dutch cutter fleet [50]'.

surrounding these distributional issues at firm level have often led to crisis, as is illustrated by the strike of Icelandic fishermen in 1994 and 1995 to protest against the ITQ system in this country.

${ }^{7}$ The Sablefish and halibut longline fisheries off Alaska are exceptions, as in these fisheries, crew members also received shares of the TAC [47].

${ }^{8}$ In this case, the authors stress that it may not have meant a reduction in overall employment in the fishery, measured in terms of working time, as the reduction in the number of fishermen employed may have been compensated by spreading their activity over longer periods of time.

${ }^{9}$ The extent to which this reduced quality of life is compensated by better wages is not clear in these studies. 
The second important effect to consider is the evolution of remunerations observed where individual quota regimes have been implemented. In theory, as stated by Wilen and Casey [46], regimes in which quotas have a positive value could lead to alterations of share systems, in a manner which is difficult to predict given the close relationships (or identity) between vessel owners and skippers frequently observed in fisheries. According to some authors at least, there is a possibility that returns to crews may fall if share agreements change following the integration of costs of purchasing quotas and opportunity costs of using them.

Thus according to [51] :

"Wages to crew may change if owners readjust the share system to enhance their profit or to maintain their position within increasingly competitive industry or to account for the cost of purchased quotas. (...) Returns to crew may fall if crew-share agreements change to reflect the cost of obtaining ITQs and the opportunity cost of using them ${ }^{\prime 10}$

This has been observed in a number of instances. In the SCOQ case, vessel owners generally reduced crew shares, justifying this in terms of having to cover the cost of quota purchases [11]. Reductions in crew shares have also been noted by these authors on Nova Scotia vessels. In the same fishery, other practices by owners have consisted in transferring lease fees to crews, or in charging the cost of quotas as a percentage of the value of landings at ex-vessel price. This behaviour is also common in Iceland where long term contracts have been negotiated between integrated fishing companies and inshore vessel owners with little or no quota. The latter sell their catch to the former at a price lower than the auction price, that takes into account the lease paid to quota-owners [53]. As a result of such mechanisms, up to $50 \%$ wage decreases have been observed in the Icelandic case, in a context of limited employment alternatives for fishermen [54]. Copes [29] also notes that in other cases where, as previously discussed, active fishermen have been working for longer periods of time under ITQ regimes, they have also had less spare time to find complementary incomes from other activities.

\footnotetext{
${ }^{10}$ The changes in remuneration discussed here are not only observed in ITQ regimes, but more generally in any transferable rights system. Thus, in the Canadian west coast herring fishery, managed by transferable licences, each fisherman must pay an access fee $(10000 \$)$ to purse seine vessel owners in order to be employed in the fishery; this advance is used by vessel owners to cover the cost of the fishing licence [52].
} 
Following the implementation of ITQs, there have thus been instances in which the share of returns going to crew labour has been reduced. As observed by [44], such evolutions may be interpreted as the logical consequence of a reduction in the importance of labour relative to other inputs - and in particular of rights to catch - on fishing vessels. In the context of internal bargaining within fishing firms, it may also be interpreted as a the outcome of conflicts between capital owners and crew members in the allocation of the real or opportunity costs of using quotas.

Unlike the above cases, the shift to ITQs in the British Columbia halibut fishery seems to have led to an increase in crew remunerations for most of the remaining fishermen [46]. This is notwithstanding the fact that overall crew shares have been reduced, and results mainly from the fact that the ITQ regime has allowed to spread landings over the year leading to changes in product handling and quality, and to higher ex-vessel prices.

Overall, it thus appears that ITQ regimes create new incentive schemes for firms that may lead to new relations of production and organisation between crews, capital owners and quota owners. This reorganisation process with distributional consequences - or distributional constraint with organisational consequences - can be seen to play an important role in the capacity for fishing firms to compete for quotas and in the operation of the quota market. To anticipate the consequences of individual quota regulations requires that these organisational problems be taken into account. Next, a simple model is developed in order to simulate these dynamics.

II - A simple model at firm level.

A standard model of ITQ regime.

We assume the exploitation of a single species fishery by a fleet of $N$ fishing firms. The fleet is split in four sub-fleets $(i=1, \ldots 4)$ in order to consider differences in productivity and costs of inputs. Each firm 
(vessel) representative of sub-fleet (i) is able to catch the quantity of fish $y_{i t}$ defined by a stock-flow relationship of the following form :

$$
y_{i t}=q_{i} E_{i t}^{\alpha_{i}} B_{t} \quad \forall i=(1, \ldots 4)
$$

(2) $\quad L_{i t}=E_{i t} /$ url

Crew size $L_{i t}$ is variable only within a restricted range and is a function of the rate of labour utilisation $(u r l)$ and quasi-fixed factors. The same opportunity cost of labour $(o c l)$ applies to all crew members.

$E_{i t}$ is a scalar and represents variable inputs. $B_{t}$ is an index of biomass and $q_{i}$ is assumed to vary according to vessel category in order to introduce economies of scale. $\alpha_{i}$ captures the existence of decreasing marginal yields. Firms are price takers with $p$ the price of landings, $c$ the unit price of variable inputs and $\left(o c_{i}\right)$ the opportunity cost of capital. The profit function for each representative firm can be written as follows:

$$
\pi_{i t}=p y_{i t}-c E_{i t}-o c_{i}
$$

It is assumed that the management authority decides to fix and share a T.A.C., allocated free of charge to firm owners in the form of individual quotas in weight :

$$
\text { (4) } \overline{y_{i t}}=\partial_{i}-T A C_{t} \quad \sum_{i=1}^{N} \partial_{i}=1
$$

where $\overline{y_{i t}}$ is the individual quota endowment of each representative firm and $\partial_{i}$ the individual fixed share of the TAC. Standard theory shows that this new constraint on the production possibility set induces the fishing firm to adjust variable inputs in order to minimise its costs. In the case of quota transferability and especially of quota leasing markets, each owner can buy or sell quota units ${ }^{11}$ in order to match his quota with the desired (optimal) production level. Let $l_{t}$ be the rental price of one unit of quota in current period. $l_{t} \cdot d_{i t}$ is the cost (earning) of purchasing (selling) quotas where $d_{i t}=y_{i t}^{*}-\overline{y_{i t}}$ is the individual net demand for quota. $l_{t} \cdot \overline{y_{i t}}$ is the opportunity cost of using quota.

\footnotetext{
${ }^{11}$ Perfect divisibility of quotas is assumed.
} 
As $p-l_{t}$ represents the net marginal benefit of harvesting an additional unit, it is interesting for firms to buy an additional unit of harvest right as long as this net marginal benefit is higher than or equal to the marginal cost of producing this extra unit. When the net marginal benefit equals the marginal production cost (i.e. marginal profit is equal to the quota lease rate), net demand clears and the quotaleasing market is in equilibrium. Clearly, transferability leads to Pareto efficiency if the quota market is perfect. In this model, a walrasian process of adjustment being assumed, the situation of all firms is improved - and all potential gains from trade are exhausted - after trading.

At equilibrium, the difference between landing price and marginal production cost measures the rental market price, and is maximum at the minimum of the average cost curve. Standard effects of quota trade thus modelled are the equalisation of marginal production costs between firms, and the increase in individual and global quasi-rents at equilibrium. Note that the same results would appear in the case of individual transferable licence programs with for example, transactions on days at sea. In this case; harvest rights become a new production factor without which it is not possible to produce and the quota price (or the transferable right to use input) represents the remuneration of rights services.

Results of a simulation run, using the software Stella, are presented in tables 1 to 3.

Table 1. Comparison of firm situation before and after quota exchange

Parameters used in simulation : $\mathrm{a}=0.8 / \mathrm{q} 1=0.7 / \mathrm{q} 2=0.8 / \mathrm{q} 3=0.9 / \mathrm{q} 4=1 / \mathrm{c}=1 / \mathrm{Oci}=10 / \mathrm{TAC}=40$

\begin{tabular}{lccccc}
\hline & Initial quota allocation & Initial surplus & $\begin{array}{c}\text { Final quota } \\
\text { allocation after trade }\end{array}$ & $\begin{array}{c}\text { Final surplus } \\
\text { after trade }\end{array}$ & $\begin{array}{c}\text { Rental price } \\
\text { at equilibrium }\end{array}$ \\
\hline Firm 1 & 10 & 51.13 & 3.2 & 67.64 & \\
Firm 2 & 10 & 72.48 & 6.3 & 75.65 & \\
Firm 3 & 10 & 88.57 & 11.3 & 88.83 & \\
Firm 4 & 10 & 101.09 & 19.2 & 109.37 & 6.92 \\
& & & & & \\
\hline
\end{tabular}


Table 2. Sensitivity analysis on T.A.C sharing between firms (T.A.C=40)

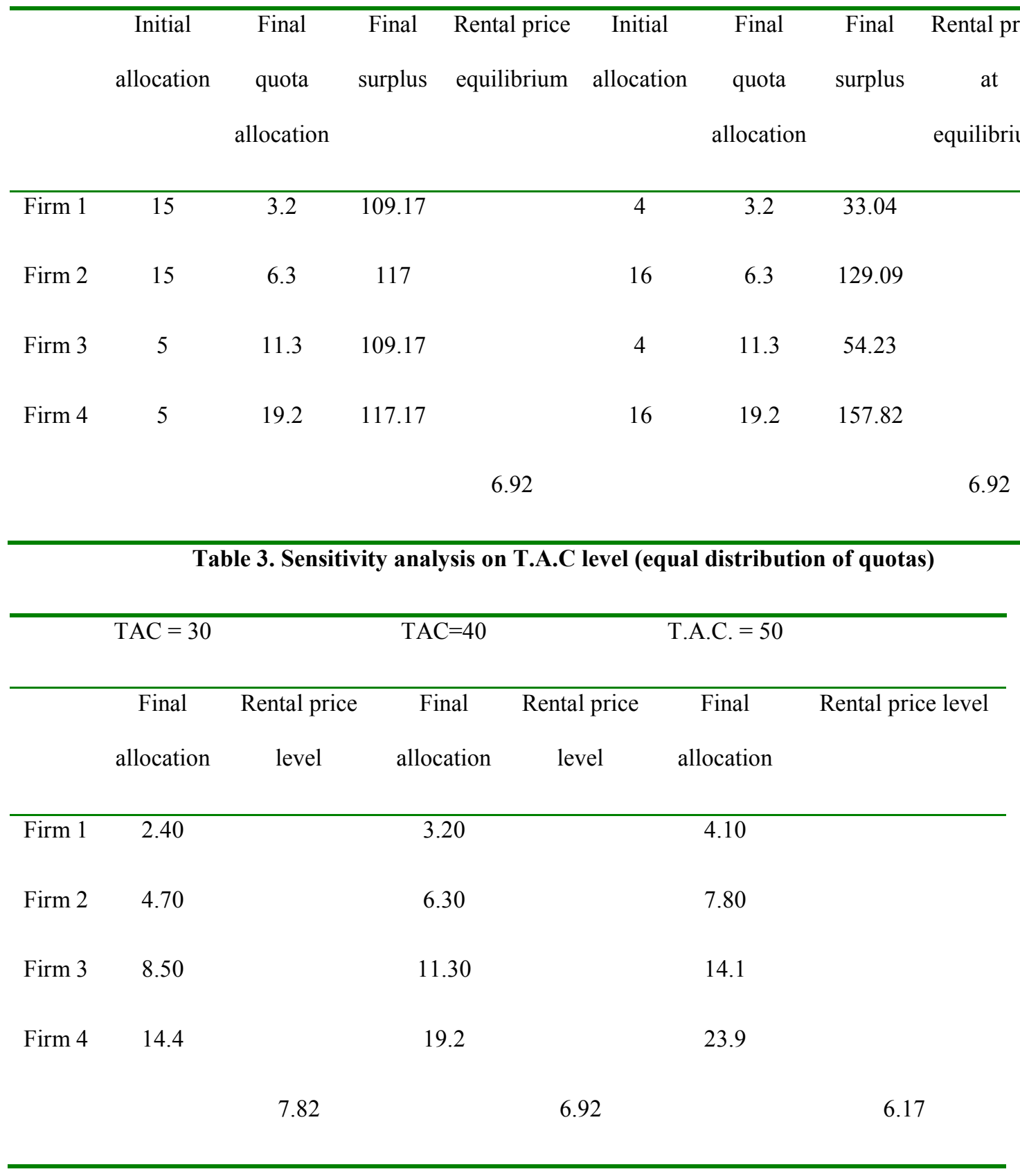


Note that the rental price for quota depends on global demand and supply (TAC) and that it does not truly capture resource rent but quasi-rent when all production factors are not at their optimal level ${ }^{12}$

\section{An extension of the model to consider short-term distributive effects within firms}

Although this model provides an interesting tool to assess wealth and distributive consequences of the implementation of ITQ schemes at fleet level, it fails to consider within firm distributive aspects. The weakness of the analysis on this issue comes from the fact that the firm is considered as a black box. In most fisheries, the remuneration of labour and capital services is based on a share system [55]. While many systems exist in practice, they all have the common objective to provide economic incentives through revenue sharing [56], in the context of a relationship which can be analysed from a principal-agent perspective.

Under share systems, crew members may collect part of the rent or quasi-rents (e.g. infra-marginal rents) over their opportunity cost. Let us assume that crew remuneration $(\mathrm{Cr})$ depends on the value of catches (p.y) minus shared costs (c.E) :

(6) $\quad 0 \leq \delta_{i} \leq 1$

Furthermore, the decision units involved in trading on the quota market are assumed to be the capital owners, to whom individual rights are allocated initially, and who make decisions about the optimal catch and related quota purchases (sales).

Sensitivity analysis on model parameters allows us to assess the effects of changes in the share rate $(\delta)$ and the $(u r l)$ on the evolution of firm performance on the market for quota and on employment. Results of such an analysis are presented in the following table.

\footnotetext{
${ }^{12}$ Thus, throughout 1994-1995, the rental price for cod quotas in Iceland has been relatively high (estimated at $70-80 \%$ of the average price of cod catches by [53], and it appears that, although this can be partly attributed to the fleet rationalisation process through ITQ implementation, it has been strongly influenced by TAC reductions over this period due to the poor state of the stocks.
} 
Table 4. Sensitivity analysis on share rate and optimal production

\begin{tabular}{|c|c|c|c|c|}
\hline Share-rate & $\delta_{4 a}=$ & $\delta_{4 b}=$ & $\delta_{4 c}=$ & $\delta_{4 d}=$ \\
\hline$\delta_{i}=0.3$ for $\quad i=1,2,3$ & 0.3 & 0.333 & 0.367 & 0.4 \\
\hline Firm 1 production level & 3.2 & 3.4 & 3.5 & 3.7 \\
\hline Firm 2 production level & 6.3 & 6.6 & 6.9 & 7.2 \\
\hline Firm 3 production level & 11.3 & 11.9 & 12.5 & 13.1 \\
\hline Firm 4 production level & 19.2 & 18.1 & 17.1 & 16.0 \\
\hline Rental price & 4.84 & 4.74 & 4.62 & 4.51 \\
\hline Quota value & 239.0 & 233.4 & 228.0 & 222.0 \\
\hline Crew rent & 102.9 & 107.9 & 112.7 & 116.9 \\
\hline Vessel owner rent & 194.6 & 189.6 & 184.8 & 180.6 \\
\hline Total rent & 536.5 & 530.9 & 525.5 & 519.5 \\
\hline
\end{tabular}

As shown in table 4, a higher share rate for representative firm 4 leads to decreasing willingness to pay for quota units and decreasing optimal production for this firm, and to a change in its competitive position on the market for rights. As a consequence, the allocation of TAC between firms and the rental price for quota are also modified.

Firm willingness to pay for quota units depends on their ability to reduce unit variable costs and especially crew remuneration : obviously, willingness to pay for an additional unit of quota will be larger where the crew supports part of the cost. The smaller the crew rate, the higher the willingness to pay for quota, which depends on the marginal cost of production (including marginal cost of crew remuneration). Even if firm 4 is the most efficient from a technical point of view, the weakness of its capital owner in bargaining with the crew can affect its bargaining power on quota markets. The 
implication is that the most cost-efficient operators on quota markets will likely be those who, not only are the most efficient in terms of fishing operations, but also who have best been able to reorganise their internal structure, particularly as regards contracts between vessel owners and crews. We may expect that such a re-organisation should proceed all the more quickly as the TAC is restrictive, leading to increased competition between firms in order to remain in the fishery.

From a comparative statics perspective, each scenario leads to an optimum given the internal institutional structure of existing firms, and it is thus difficult to make comparisons between them on efficiency grounds. From a dynamic perspective, we can expect that there will be an incentive for capital and quota owners to switch from scenario 4 to 1 , in order to increase their rent flows. The nature of this process, which involves bargaining between owners and crews, would thus need to be modelled in order to fully represent the evolution of the management system.

Sensitivity analysis on the rate of labour utilisation can also be carried out. By construction of the model, factor rationalisation through quota adjustment yields lower levels of employment (see table below).

Table 5. Sensitivity analysis on rate of labour utilisation

\begin{tabular}{ccccc}
\hline & $u r l=10$ & url=13.3 & url=16.7 & url $=20$ \\
& & & & \\
\hline Initial labour & 8.93 & 6.70 & 5.36 & 4.47 \\
Final labour & 8.37 & 6.28 & 5.02 & 4.19 \\
\hline \multicolumn{4}{c}{$u r l:$ utilisation rate of labour }
\end{tabular}

A further step here would be to make $u r l$ an endogenous variable in the model, with maximum and minimum constraints. The simulation would then allow to explore changes in this variable as a function of the various policy options and allocation scenarios considered. Such a simulation model has been applied to a real fishery - the French driftnet albacore fishery - using empirical data [32, 57]. Results are similar to those described above. 


\section{Further developments}

Although this model of an individual quota regime and the straightforward sensitivity analysis on parameters that relate to distributional issues within fishing firms provide some insight on how such issues might affect the overall operation of the management system from an economic perspective, it remains a very simplified approach of the dynamics which need to be taken into account for such assessments in practice. Additional work in modelling organisational and bargaining relations within firms and within the fishing industry certainly appears as an interesting direction for future research in this area. Useful insights could also be gained from the application of a similar approach to the analysis of management systems at national, and international levels. 


\section{References.}

[1] Christy F. T. Jr, (1973). "Fishermen Quotas : A Tentative Suggestion for Domestic Management", Law of the Sea Institute University of Rhode Island, Occasional paper No. 19, Kingston, Rhode Island.

[2] Moloney D. G. andP. H. Pearse (1979). "Quantitative Rights an Instrument for Regulating Commercial Fisheries", J. Fish. Res. Board Can., $36: 859-866$.

[3] Scott, A. (1988). Development of property in the fishery. Marine Resource Economics. 5: 289-311. [4] Neher, P. A. E., R. E. Arnason, et al. (1989). Rights based fishing. Proceedings of a workshop on the scientific foundations for right based fishing, Reykjavik, June 27- July 1, 1988. WORKSHOP ON THE SCIENTIFIC FOUNDATIONS FOR RIGHTS BASED FISHING (1988 ; Reykjavik): XIV-541 p. : fig., tabl. ; $25 \mathrm{~cm}$.

[5] Arnason, R. (1991). Efficient management of ocean fisheries. European Economic Review. 35: 408-417.

[6] Hannesson, R. (1991). From common fish to rights based fishing. European Economic Review. 35: 397-407.

[7] Bjorndal, T. and G. Munro (1997). The economics of fisheries management : A survey. Papers on Fisheries Economics: 41p.

[8] FAO (1993). Marine fisheries and the law of the sea : a decade of change. Rome, FAO fisheries circular.

[9] Troadec, J. P. (1994). Le nouvel enjeu de la pêche : l'ajustement des institutions aux nouvelles conditions de pleines exploitation des stocks. Comptes-rendus de l'académie d'agriculture de France. 80: 41-60.

[10] Hannesson, R. (1996). Fisheries mismanagement. The case of the North Atlantic Cod. Fishing News Books, Oxford : 160p. 
[11] McCay, B. J., C. F. Creed, et al. (1995). Individual transferable quotas (ITQs) in Canadian and US fisheries. Ocean and Coastal Management. 28: 85-115.

[12] Macinko, S. (1993). "Public or private ? : United States commercial fisheries management and the public trust docrtine, reciprocal challenges.” Natural Resource Journal 33: 919-955.

[13] Johnson, R. N. and G. D. Libecap (1982). Contracting problems and regulation : the case of the fishery. American Economic Review. 72: 1005-1022.

[14] Karpoff, J. M. (1987). Sub-optimal controls in common resource management : the case of the fishery. Journal of Political Economy. 95: 179-194.

[15] Scott, A. (1993). Obstacles to fishery self-government. Marine Resource Economics. 8: 187-199.

[16] Christy, F. T. (1996). Paradigms lost : the death rattle of open access and the advent of property right regimes in fisheries. Communication présentée à la huitième conférence bi-annuelle de l'Institut International d'Economie des Pêches, Marrakech.

[17] Copes, P. (1986). A critical review of the individual quota as a device in fisheries management. Land Economics. 62: 278-291.

[18] Copes, P. (1997). Adverse impacts of individual quota systems on conservation and fish harvest productivity. Discussion Paper 96-1presented at the 10th EAFE, Quimper.

[19] Matthiasson, T. (1992). Principles for distribution of rent from a 'commons'. Marine Policy: 210231.

[20] Karpoff J. M., (1989). "Characteristics of Limited Entry fisheries and the Option Component of Entry Licenses", Land Economics, 65 : 386-393.

[21] Edwards, S. F. (1994). Ownership of renewable ocean resources. Marine Resource Economics. 9: 253-273.

[22] Copes, P. (1998). The extended economics of an innate common use resource : the fishery. Paper presented at the ninth biennial conference of the international institute of fisheries economics and trade, Tromso. 
[23] Charles, A. T. (1988). Fishery socioeconomics : a survey. Land Economics. 64: 276-295.

[24] Charles, A. T. (1994). Towards sustainability : the fishery experience. Ecological Economics. 11: 201-211.

[25] Hanna, S. and M. Munasinghe (1995). Property rights and the environment : Social and Ecological issues. Washington, The Beijer International Institute of Ecological Economics and The World Bank.

[26] Armstrong, C. W. and D. J. Clark (1997). Just fishing ? Equity and Efficiency in fisheries management regimes. Marine Resources Economics. 12: 203-220.

[27] Palsson, G. and G. E. Petursdottir (1997). Social implications of quota systems in fisheries. Copenhague, TemaNord.

[28] Bromley, D. W. and R. C. Bishop (1977). From economic theory to fisheries policy : conceptual problems and management prescriptions. Economic aspects of extended fisheries jurisdiction. Mishigan, An Arbor Science Publishers Incorporated: 281-301.

[29] Copes, P. (1997). Social impacts of fisheries management regimes based on individual quotas. Social implications of quota systems in fisheries. Proceedings of a seminar held in the Vestman Islands, Iceland: 61-90.

[30] Bromley, D. W. (1977). Distributional implications of the extended economic zone : some policy and research issues in the fishery. American journal of agricultural economics. 59: 887-892.

[31] Cunningham, S. (1994). Fishermen's incomes and fisheries management. Marine resources economics, $9(3): 241-252$.

[32] Guyader, O. (1998a). Evaluation économique et simulation des effets des régulations sur les comportements des agents : le cas des pêcheries de thon germon de l'Atlantique Nord Est. Thèse de doctorat Université de Rennes 1: 420p. 
[33] Thébaud, O. (1998). Les choix collectifs de conservation des ressources marines vivantes: analyse économique appliquée aux cas des pêcheries coralliennes et de l'exploitation internationale des grands cétacés. Thèse pour le Doctorat de l'EHESS, Paris : 470p.

[34] Bergh (van den) J.C.J.M.,Carbonell, A.F., Munda, G. (1998). Models of individual behaviour and implications for environmental policy. Working paper, Free University Amsterdam.

[35] Hannesson, R. (1985). Inefficiency through government regulations : The case of Norway's fishery policy. Marine Resource Economics. 2: 115-141.

[36] Boncoeur, J. and B. Mesnil (1997). Surexploitation des stocks et conflits dans le secteur des pêches. Une discussion du "triangle des paradigmes" d'Anthony Charles dans le contexte européen. Association Française d'Halieumétrie - 3ème forum halieumétrique, Montpellier.

[37] Matulich, S. C., R. C. Mittelhammer, et al. (1996). Toward a more complete model of individual transferable fishing quotas : implications of incorporating the process sector. Journal of environmental economics and management. 31: 112-128.

[38] Sharp, B. M. (1998). Integrating recreational fisheries into rights based management systems. Paper presented at the first world congress of environmental and resource economics, Venice - Italy.

[39] Memon, P. A. Cullen, et al. (1992). Fishery policies and their impact on the New Zealand Maori. Marine Resource Economics. 7: 153-167.

[40] OCDE (1997). Towards sustainable fisheries : economic aspects of the management of living marine resources. Paris, OCDE publications.

[41] Davidse, W. E. (1997). Property rights in fishing; effects on the industry and effectiveness for fishery management policy, LEI-DLO.

[42] Geen, G. and M. Nayar (1989). Individual transferable quotas in the southern bluefin tuna fishery: an economic appraisal". Rights based fishing, Neher P.A and al (eds) NATO ASI Series: 355-381.

[43] Anonyme (1994). "Information paper on the southern bluefin tuna fishery". The Australian fisheries management authority: $6 \mathrm{p}$. 
[44] Casey, K. E., Dewees, et al. (1995). The effects of individual vessel quotas in the British Columbia halibut fishery. Marine Resource Economics. 10: 211-230.

[45] Wang, S. (1995). The surf clam ITQ management : an evaluation - Thalassorama. Marine Resource Economics. 10: 93-98.

[46] Wilen, J. E. and K. Casey (1997). Employment and remuneration effects. Social implications of quota systems in fisheries. Copenhagen, Gisli Palsson, Petursdottir Gudrun (Eds): 315-333.

[47] Terry, J. M. (1993). Quotas individuels transférables pour la pêche à la morue charbonnière et au flétan avec des engins fixes au large de l'Alaska. L'utilisation des contingents dans la gestion des pêches, OCDE: 103-130.

[48] McCay B. J., (1995). Social and Ecological Implication of ITQs : An Overview. Ocean \& Coastal Management, 28: 3-22.

[49] Binkley, M. (1989). Nova Scotian offshore groundfish fishmen - Effects of the enterprise allocation and the drive for quality. Marine Policy: 274-284.

[50] Smith, W. (1996). A case study : the dutch co-management system. European association of fisheries economist conference, 1-3 April, Barcelona.

[51] Squires, D, Kirkley, J, Tisdell, C (1995). Individual transferable quota as a management tool. Reviews in fisheries science $3: 141-169$.

[52] Fisherman Vancouver B. C., (1987), Feb 23, p. 8

[53] Eythorsson, E. (1996). Theory and practice of ITQs in Iceland : privatization of common fishing rights. Marine Policy. 20: 269-281.

[54] Palsson, G. and A. Helgason (1995). Figuring fish and measuring men : the individual transferable quota system in the Icelandic cod fishery. Ocean and Coastal Management. 28: 117-146.

[55] Platteau, J.P., Nugent (1989). Contractual relationships and their rationale in marine fishing. Cahiers de la Faculté des Sciences Economiques et Sociales de Namur, May. 
[56] Sutinen, J-G (1979). Fishermen remuneration systems and implications for fisheries development. Scottish Journal of Political Economy 26 (2).

[57] Guyader, O. (1998b). Simulation de la mise en oeuvre de quotas individuels transférables et application à la pêche germonière. La dynamique des systèmes - Complexité et chaos. Paris, Hermes: 147-169. 